\title{
The Río Parapetí - Holocene megafan formation in the southernmost Amazon basin
}

\author{
Jan-Hendrik May, Wollongong
}

\section{Introduction}

Megafans may potentially store long records of regional uplift, denudation and climate history over long geologic timescales due to their extensive surface areas and large sediment volumes (HorTon \& DeCelles 2001; Uba et al. 2007). On much shorter timescales, however, they are characterized by highly dynamic fluvial processes of severe flooding and frequent avulsions (Chakraborty et al. 2010; Wells \& DORR 1987). The spatial and temporal variability of these processes ultimately determine the environmental, hydrological and ecological properties across extended foreland areas (WILKINSON et al. 2006). The Andean foreland in eastern Bolivia is characterized by three megafans: the Río Grande (Guapay), Río Parapetí and Río Pilcomayo (Horton \& DeCelles 2001; IRIONDO 1993; MAY 2006), the latter being among the largest known megafans of the world (HARTLEY et al. 2010). For all of these, large-scale channel shifts have been identified based on remotely sensed detection of paleochannels (Horton \& DeCELles 2001; Werding 1977a), illustrating that the Río Parapetí has become part of the southernmost Amazon catchment only in the late Quaternary, and formerly drained towards the Paraná and La Plata basins in the south (BARBoza et al. 2000; LATrubesse 2003). Today, the Parapetí contributes surface water to the Amazon only occasionally, and terminates in the Bañados de Izozog wetlands (ARGOLLo 2006). As a function of seasonal flooding, these wetlands sustain a highly diverse wildlife and flora (NAVARRo \& MALDONADo 2002), and were consequently declared a «Ramsar» protection site in 2001 (Convention on Wetlands of International Importance, www.ramsar.org). For the local indigenous Guaraní people, who inhabit the area at least since the 15 th century, this peculiar setting is of fundamental cultural and economic importance, allowing for fishing, irrigation and agriculture within the otherwise dry environment of the Gran Chaco (OrTIZ et al. 2008). Even though the link between these highly fragile wetland habitats and the larger-scale processes operating on the megafan may be obvious, as yet there is no sound geoscientific understanding of the geomorphic history of the Río Parapetí, and a number of relevant questions remain to be answered: Which are and were the geomorphic processes operating on the megafan, what are their variabilities and controls, and how have they contributed to the evolution of the Río Parapetí over different late Quaternary timescales? In order to address these questions, this paper intends to (i) present a detailed description of landforms along the Río Parapetí and its megafan, (ii) provide first stratigraphic and chronological data for the Bañados de Izozog, and (iii) discuss these data within the larger-scale framework of late Quaternary and Holocene megafan and wetland evolution in the eastern Bolivian foreland.

\section{Regional setting}

The Chaco plain (Gran Chaco) encompasses most of the modern Andean foreland in eastern Bolivia (Fig. 1a) and is bordered by the fold-and-thrust belt of the Subandes to the west (BABY et al. 1992), and the «Alto de Izozog» to the east (MAY 2006; UBA et al. 2006). Compared to the adjacent Río Grande and Pilcomayo megafans, the Río Parapetí occupies a much smaller catchment area of $\sim 7500-8000 \mathrm{~km}^{2}$ almost exclusively situated in the Subandean Zone and rising to $\sim 3300 \mathrm{~m}$ asl in the upper catchment (BARNes \& HeIns 2009). Below, the antecedent Río Parapetí cuts through multiple anticlines and reaches its catchment outlet at the megafan apex at $\sim 600 \mathrm{~m}$ asl in the vicinity of San Antonio de Parapetí. From here, its megafan covers an area of at least $5800-6800 \mathrm{~km}^{2}$ in the Chaco plain with average gradients ranging from 0.003 to 0.0014 (BARNES \& HeINS 2009).

Climatically, eastern Bolivia is situated in a transitional setting between the tropical humid Amazon basin to the north and the semi-arid Chaco plain to the southeast, leading to strong hydroclimatic seasonality (Fig. 1a, b). Most annual precipitation falls during the wet season from December to March through convective storms related to the South American Summer Monsoon (SASM), averaging less than $700 \mathrm{~mm} / \mathrm{a}$ in the semi-arid Chaco plain, but locally exceeding $1000 \mathrm{~mm} / \mathrm{a}$ in the Parapetí catchment due to orographic effects along the main anticlines of the Subandes (AGTECA 2010; BookHAgEN \& STRECKER 2008; VERA et al. 2006). Moisture is transported southward by a low level jet (South American Low-Level Jet SALLJ), which is responsible for very strong northerly winds in the Bolivian Chaco throughout the year with a peak during the dry season (Fig. 1b; AGTECA 2010; BERRI \& InZunZa 1993). Catchment vegetation is characterized by various semi-deciduous forest types, but anthropogenic impacts have caused some degra- 


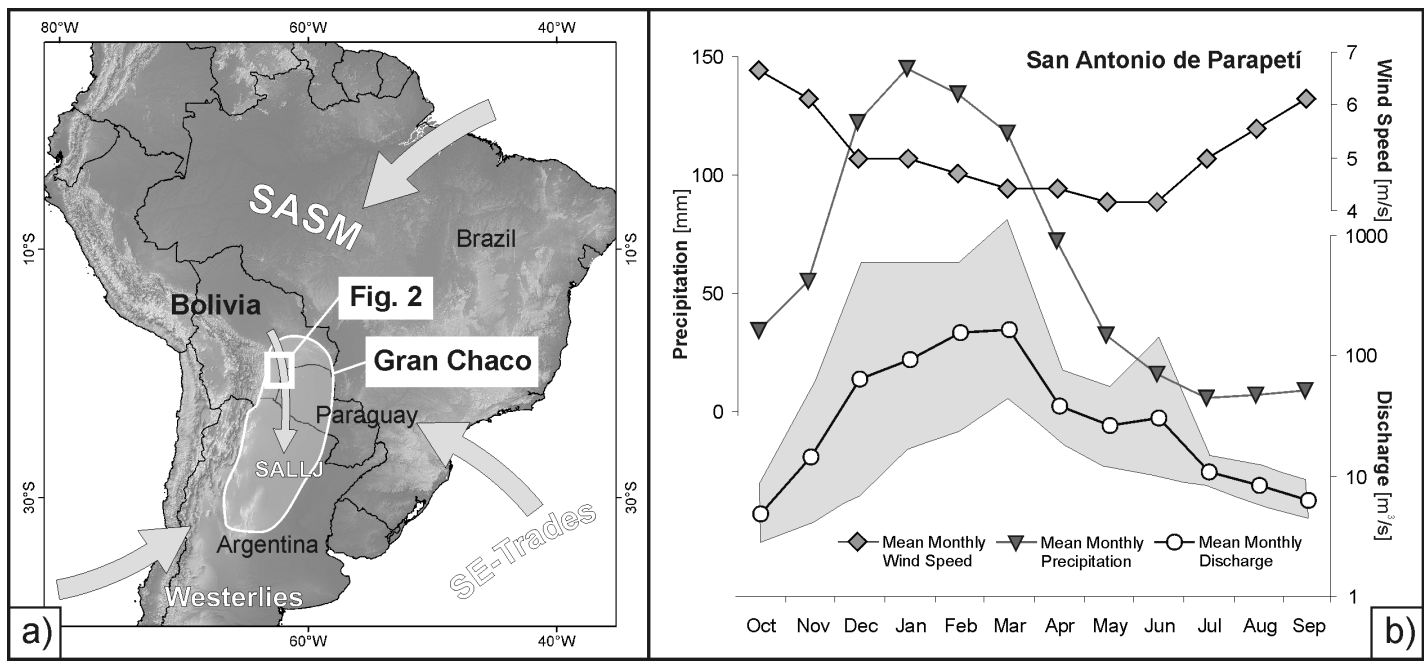

Fig. 1: Geographic and hydroclimatic setting of the study area: a) location of the Gran Chaco in South America; b) hydroclimatic variables as measured at San Antonio de Parapetí

Geographischer und hydroklimatischer Rahmen des Untersuchungsgebietes: a) Lage des Gran Chaco in Südamerika; b) hydroklimatische Parameter gemessen in San Antonio de Parapetí

Conditions géographiques et hydroclimatiques de la zone d'étude: a) localisation du Gran Chaco en Amérique du Sud; b) variables hydroclimatiques mesurées à San Antonio de Parapetí

Source: a) Riveros 2004; b) Agrar- Und Hydrotechnik GmbH 1974; AGTECA 2010

dation and soil erosion (GEROLD 1985). On the plains, the semi-deciduous Chaco dry forest of variable density is interspersed with patches of palm forests and savannah type vegetation (IBISCH et al. 2004; NAVARRo $\&$ MALDONADO 2002). The resulting vegetation pattern commonly reflects local differences in soils and lithology (GEROLD 2004), and thereby mimics the largerscale geomorphic pattern of relict landforms on the megafan.

Only very limited data exist regarding the average annual discharge of the Río Parapetí, and reported values range between $\sim 38$ and $90.9 \mathrm{~m}^{3} / \mathrm{s}$ (AGRAR- UND Hydrotechnik GmbH 1974; Guyot et al. 1994). More importantly, however, discharge is characterized by very high seasonal and intra-annual variability with a pronounced flood peak in February or March, when discharges in excess of $4000 \mathrm{~m}^{3} / \mathrm{s}$ have been observed (Fig. 1b; Agrar- und Hydrotechnik GmbH 1974). Interestingly, the Parapetí carries $40 \%$ of the total annual sediment load as sandy bedload, a much higher value than $\sim 0.5 \%$ in the adjacent Río Grande (WERDING 1977a). Suspended load shows a clear peak in the clay and fine silt fraction. Downstream of the apex, strong percolation into the sandy fluvial deposits is partly responsible for very high transmission losses
(Werding 1977b). Additionally, potential evaporation reaches $\sim 1400 \mathrm{~mm} / \mathrm{a}$ with a peak between September and December (AGTECA 2010). Due to the combined effect of percolation and high evaporation, the river flow usually ceases during dry season.

\section{Methods}

Landsat images and a SRTM derived digital elevation model (DEM) were integrated into ArcGIS 9.3 to extract drainage divides and megafan boundaries. Then, the images were visually interpreted to achieve a broader-scale geomorphic overview and map individual landforms. Visual interpretation incorporates colour, density and texture of the imagery, but also deduces information from elevation, vegetation and land-use patterns (VERSTAPPEN 1977). More detailed mapping of small-scale landforms such as dunes, channels etc. was additionally facilitated by the high-resolution imagery in Google Earth. During the dry season 2005 , four sediment cores of three to five metres depth were recovered along a W-E transect across the Bañados de Izozog. Following the guidelines summarized in AG Boden (1994), the cores were described with regard to grain size, colour, and main pedogenic fea- 
tures. In addition, the total organic matter of one sediment sample (Poz-19842) was radiocarbon dated at the Radiocarbon Laboratory in Poznan (Poland); the result was calibrated using Calib 6.0 at $2 \sigma$ and the calibration dataset intcal09.14c (REIMER et al. 2009; StUIVER \& ReIMER 1993).

\section{Results}

\subsection{Río Parapetí megafan geomorphology}

The Río Parapetí exits the Subandean ranges at $\sim 600 \mathrm{~m}$ asl (Fig. 2a). Contrasting with the dominantly forest-covered and inactive megafan surface, four different active geomorphic reaches are distinguished along the modern Río Parapetí: (i) For $\sim 150 \mathrm{~km}$, the river is characterized by a sand-bed channel with $\sim 2-5 \mathrm{~km}$ long sand bars, and channel widths $>1000 \mathrm{~m}$ (locally $>2000 \mathrm{~m}$ ). Source-bordering transverse crescentic and parabolic dunes delineate the southern channel margin, and generally have not migrated more than a few hundred metres away from the channel. (ii) $\sim 150 \mathrm{~km}$ downstream from the apex, the channel width rapidly decreases, then bifurcates into a large number of breaches (crevasses) and successively minor distributary channels, and terminates into a lobate splay of sediment extending 1-2 $\mathrm{km}$ into the wetland forest (Fig. 2a; i.e. «floodout», Тоотн 1999). (iii) No confined channel is developed downstream within the wetlands of the Bañados de Izozog, which receive the seasonal floodwaters. (iv) $\sim 175 \mathrm{~km}$ downstream of the apex a narrow, meandering channel of variable sinuosities ( 1.1-1.8) and $\sim 15-20 \mathrm{~m}$ channel width routes the floodwaters further downstream (Fig. 2a). The succession of these reaches may be attributed to a gradual downstream decrease in discharge, transport capacities and grain sizes commonly observed in megafans (SHUKLA et al. 2001), and the abrupt channel breakdown and well-defined floodout clearly mark the limit between the bedload dominated proximal megafan versus the medial and distal fan with sedimentation from mainly suspended sediment.

Based on geomorphic mapping, the Parapetí megafan surface can be divided into a southern half, south of $\sim 20^{\circ} \mathrm{S}$, characterized by the Lomas de Parapetí paleodunes and the lack of clearly distinguishable paleochannels, and a northern half with more diverse geomorphic pattern of paleochannels and smaller-scale paleodunes. In detail, the megafan is further subdivided into five megafan segments (Fig. 2a), each of them radiating in different directions from the apex, and generally representing a formerly active lobe of the Río Parapetí:

- Segment A exhibits only very few paleochannels at the surface on the proximal megafan and is entirely covered by the Lomas de Parapetí dune field.
- Segment B is characterized by few paleochannels; the longest of them reaches $\sim 240 \mathrm{~km}$ into Paraguay and there bifurcates and/or avulses into a number of smaller distributary channels (KRUCK 1998). This segment is sharply confined by large complexes of source-bordering dunes to the south, and by the topographically elevated Alto de Izozog to the north.

- Segment $\mathrm{C}$ has short paleochannels $(\sim 40 \mathrm{~km})$ but extensive sand lobes in its distal part, probably reflective of former floodout zones.

- Segment D has paleochannels of $\sim 60-80 \mathrm{~km}$ with frequent source-bordering paleodunes.

- Segment E has similar characteristics to segment D, but occupies the area west of the modern river, showing that the Río Parapetí is currently not located at its westernmost location.

\subsection{The Bañados de Izozog wetlands}

Between 1975 and 2010, the Parapetí channel has prograded $\sim 17 \mathrm{~km}$ northwards into the wetlands with an average progradation rate of $\sim 500 \mathrm{~m} / \mathrm{a}$, creating a series of nested splays as well as crevasse channels and failed local avulsions (Fig. 3a). Several sparsely vegetated splay-shaped areas are visible north of the active channel in 1975, indicating that splay deposition, progradation, channel avulsion and abandonment must have occurred in the area long before 1975, and probably represent recurring cycles of filling the available accommodation space in the wetlands.

Most of the profiles along a W-E transect across the Bañados de Izozog wetland transect (Fig. 2a) are built up by comparatively fine grained sediment only occasionally interrupted by coarse silts and sands (Fig. $3 b$ ). Clays, muds and silts are generally associated with deposition in slowly moving waters of overbank environments, with increasing grain size and decreasing sorting going along with increasing proximity of the channel (GuCcIONE 1993). In contrast, coarse silts and sands indicate deposition in near-channel environments such as levees or splays (BRIDGE 1984). While most sediments range in colour from greyish brown, beige, brown to orange, the upper sediments in the centre of the wetlands are very dark brown to reddish brown clays and mud of variable depths (Fig. $3 \mathrm{~b}$ ). These clays and muds overly a paleosol; they are $\sim 150 \mathrm{~cm}$ thick in the central part of the wetlands, and thin out to the west. They are thus interpreted as representative for deposition by very slowly moving water under the currently active flooding regime of the Bañados de Izozog. At their base a radiocarbon age of total organic carbon (TOC) yielded $1192 \pm$ $5214 \mathrm{C}$ years BP, corresponding to a calibrated age range of 980-1262 cal yr BP and providing the first and as yet only available estimate for the age of the wetlands. 


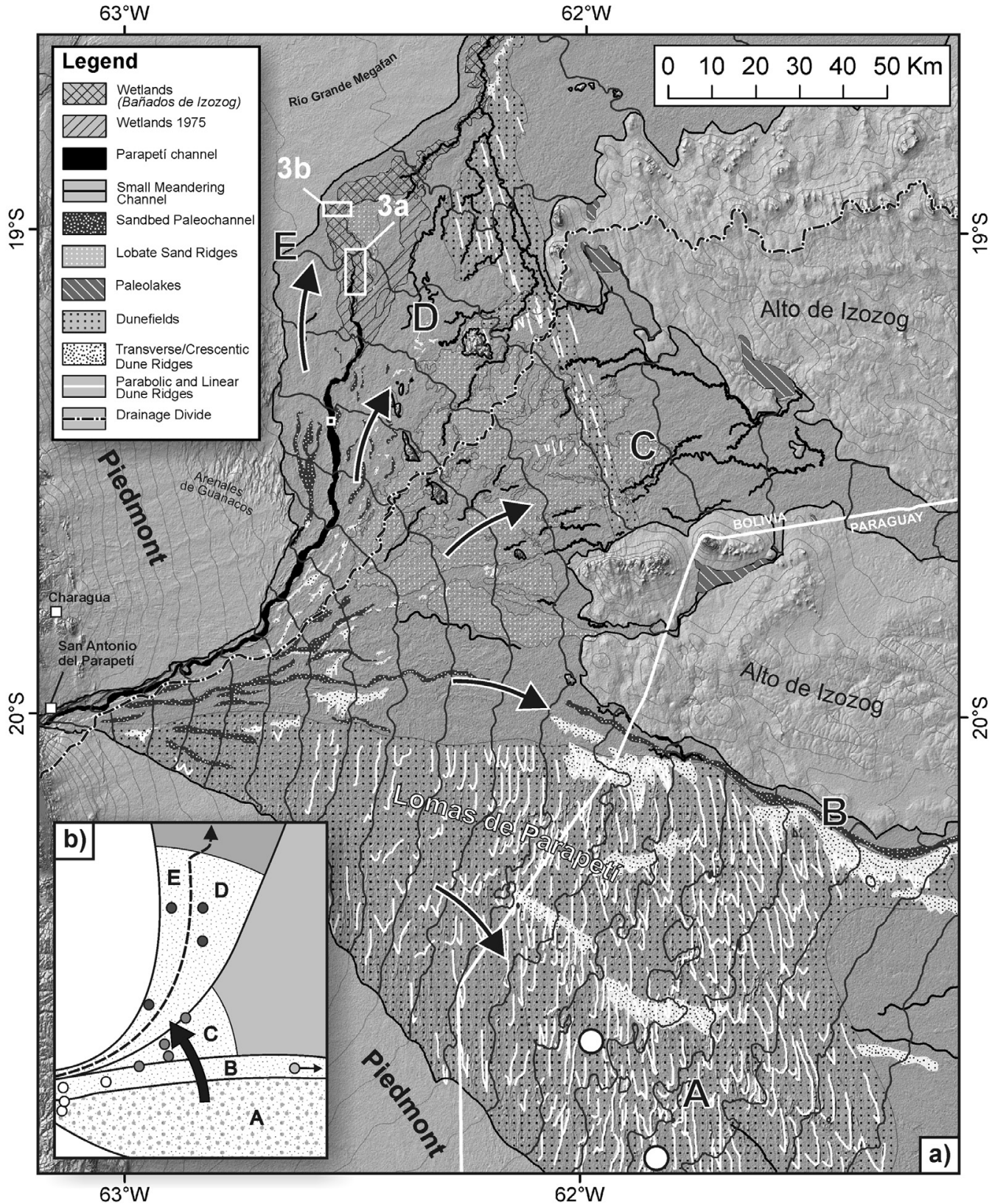

Fig. 2: Geomorphology of the Parapetí megafan: a) overview of mapped features; b) conceptual illustration of the Holocene Río Parapetí megafan evolution

A-E denote the megafan segments (see text for details), dotted areas indicate the length of paleochannels on each segment, and circles mark paleochannel divergence points (white $=$ older, black = younger).

Geomorphologie des Parapetí-Megafans: a) Überblick über die kartierten Formen; b) konzeptuelle Illustration der holozänen Megafan-Entwicklung des Río Parapetí

Géomorphologie du mégafan de Parapetí: a) aperçu des éléments cartographiés; b) illustration conceptuelle de l'évolution holocène du mégafan du Río Parapetí

Source: SRTM digital elevation model (http://srtm.csi.cgiar.org/); cartography: J.-H. MAY 


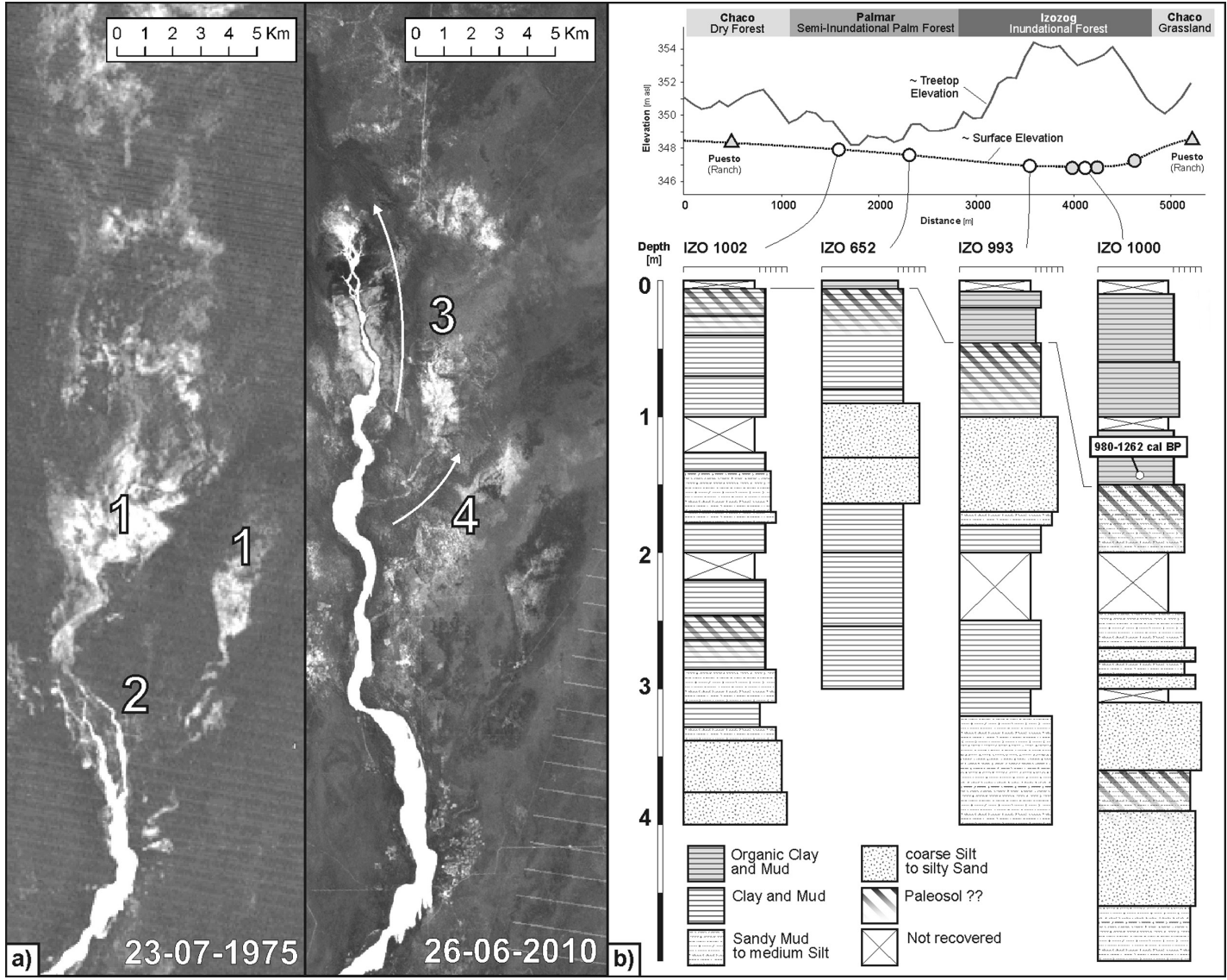

Fig. 3: Overview of recent and late Holocene evolution of the Bañados de Izozog wetlands: a) comparative satellite images of the floodout zone in 1975 and 2010 from near-infrared (band 5) Landsat images (1: older splays, 2: channel termination, 3: splay progradation, 4: crevasse channel and failed avulsion); b) stratigraphic profiles along a transect across the wetlands

Überblick über die rezente und spätholozäne Entwicklung der Bañados de Izozog-Sümpfe: a) vergleichende Satellitenbilder der «Floodout»-Zone von 1975 und 2010 auf Basis nah-infraroter (Band 5) Landsat Bilder (1: ältere Sedimentloben, 2: Ende des Flussbettes, 3: Voranschreiten der lobenartigen Sedimentation, 4: Durchbruchskanal und gescheiterte Flussumlagerung); b) stratigraphische Profile entlang eines Transektes durch die Sümpfe Aperçu des évolutions récentes et anciennes des zones humides des Bañados de Izozog pendant l'Holocène: a) comparaison de la zone d'épandage en 1975 et 2010, images Landsat infrarouge proche (bande 5) (1: anciens deltas, 2: fin des chenaux, 3: progression des deltas, 4: crevasse sur chenal et avulsion manquée); b) profils stratigraphiques le long d'un transect de zones humides

Source: USGS (http://edcsns17.cr.usgs.gov/NewEarthExplorer/)

\section{Discussion and interpretation}

Despite its significantly smaller catchment and megafan area as compared to those of the large, adjacent megafans of the Río Grande and Río Pilcomayo, the Río Parapetí megafan is characterized by a wide range of landforms variably distributed over the fan, indicat- ing changes in geomorphic processes and/or environments over time.

Over the recent decades, crevassing, channel and splay progradation into the wetlands have been the dominant geomorphic processes on the megafan. It is likely that the spatial and temporal vari- 
ability of these processes are directly controlled by the highly variable flow regime of the Río Parapetí, and thereby strongly linked to precipitation in the Subandean catchment (Fig. 1b). In this context, the seasonal to inter-annual rates of sediment supply and aggradation effectively create the topographic set-up for avulsion (Jones \& Schumm 1999; SLINGERLAND \& SMITH 2004). Contrasting with this spatially constrained short-term history of the floodout zone, shifts over much larger areas are manifest on the Río Parapetí megafan and require divergence points much closer to the apex. Here, the lengths and divergence points of the mapped paleochannels vary significantly between the five different megafan segments (A-E) and indicate significant shifts in transport capacity, sediment supply and dominant geomorphic processes on the individual megafan segments (Fig. 2b).

Along with the modern Río Parapetí, segments D and E lack signs of large-scale channel shifts and are characterized by progressive down-fan migration of the avulsion point probably linked to fan-head incision and terrace formation as observed at the apex (IRIONDO 1993). In combination, this likely reflects an overall stable position of the channel belt on the megafan with only minor adjustments in the floodout zone and some limited lateral accretion of sourcebordering dune/paleochannel complexes. Based on the stratigraphic data in the Bañados de Izozog, this situation has been in place for the last 1200 years. Similar to the Río Parapetí, laterally stable but prograding fluvial activity has been observed for most smaller piedmont streams around Charagua west of the megafan, and was dated to $<1000 \mathrm{cal}$ yr BP (MAY et al. 2008a). To the north, aggradation of river terraces along the Río Grande between 1700 and $<1400$ cal yr BP was followed by incision (MAY et al. 2008b). Along the Andean piedmont around Santa Cruz de la Sierra wetter conditions with incision along the Río Piraí were established after 1300 14C yr BP (SERVANT et al. 1981). This coincides well with the proposed change in fluvial activity before $\sim 1200$ cal yr BP along the Río Parapetí, and suggests that the marked shift from a W-E flow direction (segment B) during or before the activity of segment $\mathrm{C}$ towards a northerly direction (segments D, E and modern river) took place before $\sim 1200 \mathrm{cal}$ yr BP. Comparatively short paleochannels and extensive lobate floodout deposits on this segment (Fig. 2) may point to a period of environmental and climatic aridification.

This scenario invokes decreasing transport capacities, discharge and/or increased sediment supplies and sedimentation rates as potential causes for the observed river shifts. Thus, it clearly contradicts a hypothesis which considers the formation of source-bordering dune complexes responsible for most river shifting (WERDING 1977a). While source-bordering dunes are not common on segments $\mathrm{C}$, but best developed on segments D and E, they may have caused some of the lateral accretion and limited migration of the channel belt over the last $\sim 1200$ years. Larger-scale shifts and directional changes, however, probably owe to earlier avulsions closer to the megafan apex. Interestingly, several sandy paleochannels along the Río Pilcomayo megafan were TL dated to 7600-3400 years ago, equally indicating aggradation and laterally active fluvial systems (GEYH et al. 1996; PASIG 2005). Evidence for a mid-Holocene phase of drier conditions between $\sim 8000$ and $550014 \mathrm{C}$ yr BP (SERvant et al. 1981) could thus potentially explain the dynamic changes associated with activity on segment $C$. In this context, sands from parabolic paleodunes in the Lomas de Parapetí dune field on megafan segment A (Fig. 2a) were TL and OSL dated to $5500 \mathrm{BP}$ to 2900 years ago, respectively (Geyh et al. 1996; Kruck 1996). While these authors attribute dune activity to increased aridity, the dates may equally be interpreted as reflecting successively wetter environmental conditions towards increased vegetation cover and dune stabilization such as required for the formation and preservation of parabolic dunes (CHASE 2009; LANCASTER 2002; TSOAR 2005). In fact, a change towards more stable and humid late Holocene conditions between 3800 and 3000 cal yr BP has also been deduced from radiocarbon dating of paleosols in the Paraguayan Chaco (BARboza et al. 2000) and pollen evidence in NE Bolivia (Burbridge et al. 2004; MAYLE et al. 2000), and was even recorded in rising Lake Titicaca levels (Аввотт et al. 1997; BAKer et al. 2001). The mid- to late Holocene dates from paleodunes in the Lomas de Parapetí dune field represent the only available chronologic information and provide a minimum age on any older fluvial activity. In particular, the paleochannel of segment B reaches furthest to the east and thereby points to significantly increased flow and transport capacities under conditions of longer and/or intensified wet seasons compared to today. Extensive, fine-grained overbank and lacustrine sediments were dated to $12300-9800$ years ago (TL and OSL) further E on the distal Río Pilcomayo megafan (GEYH et al. 1996), and to $11500-10000 \mathrm{cal} \mathrm{yr} \mathrm{BP}$ on the Andean piedmont (MAY et al. 2008b), probably indicating widespread and intense overbank flooding during the late Pleistocene and early Holocene. In fact, a six to tenfold increase in groundwater recharge (PASIG 2005) reflects extraordinary wet conditions throughout the Bolivian Chaco at the same time, coinciding with the prominent «Tauca-Coipasa» wet phase reported from large number of records throughout the Central Andes (Aragollo \& Mourguiart 2000; Placzek et al. 2006). 


\section{Conclusions}

The in-depth analysis of the Río Parapetí megafan has documented a large variability of geomorphic processes involved in megafan evolution, both in time and space. Even though a detailed timeframe for fluvial activity is still absent, the rate and spatial extent of the documented large-scale lateral shifts of the Río Parapetí across its megafan appear to be linked to significant variability in transport capacities over the course of the Holocene with drier phases likely causing enhanced aggradation on the proximal fan, itself eventually causing avulsions and river shifts. In contrast, wetter conditions may help to stabilize the river course on any given segment, leading to floodout progradation, fan-head trenching and sedimentation along the downstream termination of the channel. In summary, these considerations (i) provide a readily testable hypothesis given the large number of paleochannels and source-bordering dunes on all mapped megafan segments: these features offer a promising opportunity for intensified future research on late Quaternary megafan evolution in the Chaco with a focus on the extensive application of luminescence dating of landforms and stratigraphy. Finally, our results (ii) highlight the role of climate and environmental change as a key control on megafan evolution on Holocene timescales via its influence on sediment supplies, flow regimes and transport capacities. These parameters consequently influence the spatial and temporal pattern of aggradation on the megafan, and are therefore crucial in determining the ecology and life cycles of wetlands such as the Bañados de Izozog (WILKINSON et al. 2006). Despite the importance of climate on shorter timescales, however, there is no question that tectonics (e.g. Andean uplift and/or subsidence in the foreland basin) play a crucial role for megafan evolution on longer, late Cenozoic timescales by creating, maintaining and renewing gradient and downstream accommodation space as necessary preconditions for the continued aggradation by these dynamic fluvial processes.

\section{Literature}

Aвbott, M.B., Binford, M.W., Brenner, M. \& K.R. Kelts (1997): A 3500 14C yr high-resolution record of water-level changes in Lake Titicaca, Bolivia/Peru.In: Quaternary Research 47, 2:169-180.

AG Boden (1994): Bodenkundliche Kartieranleitung. - Stuttgart, Hannover: E. Schweizerbart'sche Verlagsbuchhandlung.

Agrar- und Hydrotechnik GmbH (1974): Proyecto de desarrollo agroindustrial Abapo-Izozog. - Essen.

AGTECA (2010): Climate. - http://www.agteca.com/ climate.htm 11/01/2011.

Argollo, J. (2006): El Río Parapetí y los Bañados del
Izozog, Bolivia. - In: Revista UnG - Geosciencias 5, $1: 38-44$.

Argollo, J. \& P. Mourguiart (2000): Late Quaternary climate history of the Bolivian Altiplano. - In: Quaternary International 72, 1: 37-51.

Baby, P., Hérail, G., Salinas, R. \& T. Sempere (1992): Geometry and kinematic evolution of passive roof duplexes deduced from crosssection balancing: example from the foreland thrust system of the southern Bolivian Subandean zone. - In:Tectonics 11, 3:523-536. Baker, P.A., Seltzer, G.O., Fritz, S.C., Dunbar, R.B., Grove, M.J., Tapia, P.M., Cross, S.L., Rowe, H.D. \& J.P. BRodA (2001): The history of South American tropical precipitation for the past 25,000 years. - In: Science 291, 5504: 640-643.

Barboza, F., Geyh, M.A., Hoffmann, R., Kruck, W., Medina, A.N., Merkt, J. \& C. Rojas (2000): Soil formation and Quaternary geology of the Paraguayan Chaco - thematic mapping. - In: Zeitschrift für angewandte Geologie, Sonderheft 1: 49-53.

Barnes, J.B. \& W.A. Heins (2009): Plio-Quaternary sediment budget between thrust belt erosion and foreland deposition in the central Andes, southern Bolivia. - In: Basin Research 21, 1: 91-109.

BERRI, G.J. \& J.B. InZunZa (1993): The effect of the low-level jet on the poleward water vapour transport in the central region of South America. - In: Atmospheric Environment, Part A, 27, 3: 335-341.

Bookhagen, B. \& M.R. Strecker (2008): Orographic barriers, high-resolution TRMM rainfall, and relief variations along the eastern Andes. - In: Geophysical Research Letters 35: L06403.

BRIDGE, J.S. (1984): Large-scale facies sequences in alluvial overbank environments. - In: Journal of Sedimentary Research 54, 2: 583-588.

Burbridge, R.E., Mayle, F.E. \& T.J. Killeen (2004): Fifty-thousand-year vegetation and climate history of Noel Kempff Mercado National Park, Bolivian Amazon. - In: Quaternary Research 61, 2: 215-230.

Chakraborty, T., Kar, R., Ghosh, P. \& S. Basu (2010): Kosi megafan: historical records, geomorphology and the recent avulsion of the Kosi River. - In: Quaternary International 227, 2: 143-160.

Chase, B.M. (2009): Evaluating the use of dune sediments as a proxy for palaeo-aridity: A southern African case study. - In: Earth-Science Reviews 93, 1-2: 31-45.

Gerold, G. (1985): Untersuchungen zur Badlandentwicklung in den wechselfeuchten Waldgebieten Südboliviens. - In: Geoökodynamik 6:35-70.

GEROLD, G. (2004): Soil: the foundation of biodiversity. - In: IBIsch, P.L. \& G. MéridA (eds): Biodiversity: the richness of Bolivia: state of knowledge and conservation. - Santa Cruz de la Sierra, Bolivia: Editorial FAN: 17-31.

Geyh, M.A., Grosjean, M., Kruck, W. \& U. SchotTERER (1996): Sincronopsis del desarollo morfológico 
y climatológico del Chaco boreal y de Atacama en los últimos 35.000 anos AP. - In: Memorias del XII Congreso Geológico de Bolivia 1996, Tarija, Bolivia: 12671276.

Guccione, M.J. (1993): Grain-size distribution of overbank sediment and its use to locate channel positions. - In: Marzo, M. \& C. Puigdefábregas (eds): Alluvial sedimentation. - Oxford: Blackwell:185-194.

Guyot, J.L., Bourges, J. \& J. Cortez (1994): Sediment transport in the Río Grande, an Andean river of the Bolivian Amazon drainage basin. - In: OLIVE, J.J., Loughran, R.J. \& J.A. Kesby (eds): Variability in stream erosion and sediment transport. Proceedings of an international symposium held at Canberra, Australia, 12-16 December 1994. - Wallingford: IAHS Press: 223-231.

Hartley, A.J., Weissmann, G.S., Nichols, G.J. \& G.L. WARWICK (2010): Large distributive fluvial systems: characteristics, distribution, and controls on development. - In: Journal of Sedimentary Research 80, 2: 167-183.

Horton, B.K. \& P.G. DeCelles (2001): Modern and ancient fluvial megafans in the foreland basin system of the central Andes, southern Bolivia: implications for drainage network evolution in fold-thrust belts. - In: Basin Research 13, 1: 43-63.

Ibisch, P.L., Beck, S.G., Gerkmann, B. \& A. CarreTERo (2004): Ecoregions and ecosystems. - In: IBISCH, P.L. \& G. MÉrIDA (eds.): Biodiversity: the richness of Bolivia. - Santa Cruz de la Sierra, Bolivia: Editorial FAN: 47-88.

IRIONDO, M. (1993): Geomorphology and late Quaternary of the Chaco (South America). - In: Geomorphology 7, 4: 289-303.

Jones, L.S. \& S.A. Schumm (1999): Causes of avulsion: an overview. - In: SMith, N.D. \& J. Rogers (eds): Fluvial sedimentology VI. - London: Blackwell: 171-178.

KRUCK,W. (1996): Pleistoceno Superior y Holoceno del Chaco paraguayo. - In: Memorias del XII Congreso Geológico de Bolivia 1996, Tarija, Bolivia: 1217-1220.

KrucK, W. (1998): Proyecto sistema ambiental del Chaco. Inventario, evaluación y recomendaciones para la protección de los espacios naturales en la región occidental del Paraguay. - Asunción: Cooperación Técnica Paraguayo-Alemana.

LANCASTER, N. (2002): How dry was dry? Late Pleistocene palaeoclimates in the Namib Desert. - In: Quaternary Science Reviews 21, 7: 769-782.

LATrubesse, E.M. (2003): The Late-Quaternary palaeohydrology of large South American fluvial systems. - In: Gregory, K.J. \& G. Benito (eds): Palaeohydrology: understanding global change. - Chichester: Wiley: 193-212.

May, J.-H. (2006): Geomorphological indicators of large-scale climatic changes in the Eastern Bolivian lowlands. - In: Geographica Helvetica 61, 2: 120-134.

May, J.-H., Argollo, J. \& H. Veit (2008a): Holocene landscape evolution along the Andean piedmont, Bolivian Chaco. - In: Palaeogeography, Palaeoclimatology, Palaeoecology 260, 3-4: 505-520.

May, J.-H., Zech, R. \& H. Veit (2008b): Late Quaternary paleosol-sediment-sequences and landscape evolution along the Andean piedmont, Bolivian Chaco. In: Geomorphology 98, 1-2: 34-54.

Mayle, F.E., Burbridge, R. \& T.J. Killeen (2000): Millennial-scale dynamics of Southern Amazonian rain forests. - In: Science 290, no. 5500: 2291-2294.

Navarro, G. \& M. Maldonado (2002): Geografía ecológica de Bolivia: vegetación y ambientes acuaticos. - Santa Cruz, Bolivia: Centro de Ecología Simon I. Patiño.

Ortiz, E., Mendez, A., Zarzycki O., A. \& J. Bristol AlconN (2008): Fox walker on the Parapeti River, Bolivia - The origins of how we Guarani live in Íví. - In: Staller, J.E. (ed.): Pre-Columbian landscapes of creation and origin. - New York: Springer Press: 161202.

PAsIG, R.C. (2005): Ursprung und Dynamik des Grundwassers im nordwestlichen Chaco in Südamerika. PhD thesis, Bayrische Julius-Maximilians-Universität Würzburg, Institute of Geology.

Placzek, C., Quade, J. \& P.J. Patchett (2006): Geochronology and stratigraphy of late Pleistocene lake cycles on the southern Bolivian Altiplano: implications for causes of tropical climate change. - In: Geological Society of America Bulletin 118, 5-6: 515-532. Reimer, P.J., Baillie, M.G.L., Bard, E., Bayliss, A., Beck, J.W., Blackwell, P.G., Bronk Ramsey, C., Buck, C.E., Burr, G.S., Edwards, R.L., Friedrich, M., Grootes, P.M., Guilderson, T.P., Hajdas, I., Heaton, T.J., Hogg, A.G., Hughen, K.A., Kaiser, K.F., Kromer, B., McCormac, F.G., Manning, S.W., Reimer, R.W., Richards, D.A., Southon, J.R., Talamo, S., Turney, C.S.M., VAN Der Plicht, J. \& C.E. Weyhenmeyer (2009): IntCal09 and Marine09 radiocarbon age calibration curves, 0-50,000 years cal BP. - In: Radiocarbon 51, 4: 1111-1150.

Riveros, F. (2004): The Gran Chaco. - http:/www. fao.org/ag/AGP/AGPC/doc/Bulletin/GranChaco.htm 15.01.2007.

Servant, M., Fontes, J.-C., Rieu, M. \& J.-F. SAliège (1981): Phases climatiques arides holocènes dans le sudouest de l'Amazonie (Bolivie). - In: Comptes Rendus, Académie de Sciences de Paris, Série II, 292: 1295-1297. Shukla, U.K., Singh, I.B., Sharma, M. \& S. Sharma (2001): A model of alluvial megafan sedimentation: Ganga Megafan. - In: Sedimentary Geology 144, 3-4: 243-262.

Slingerland, R.L. \& N.D. Smith (2004): River avulsions and their deposits. - In: Annual Review of Earth and Planetary Sciences 2004. 32: 257-285.

Stuiver, M. \& P.J. Reimer (1993): Extended 14C database and revised CALIB radiocarbon calibration program. - In: Radiocarbon 35, 1: 215-230. 
Тоотн, S. (1999): Floodouts in Central Australia. - In: Miller, A.J. \& A. Gupta (eds): Varieties of fluvial form. - New York, London: Wiley: 219-248.

TsOAR, H. (2005): Sand dunes mobility and stability in relation to climate. - In: Physica A: Statistical Mechanics and its Applications 357, 1:50-56.

UbA, C.E., Strecker, M.R. \& A.K. Schmitt (2007): Increased sediment accumulation rates and climatic forcing in the central Andes during the late Miocene.In: Geology 35, 11: 979-982.

Uba, C.E., Heubeck, C. \& C. Hulka (2006): Evolution of the late Cenozoic Chaco foreland basin, Southern Bolivia. - In: Basin Research 18: 145-170.

Vera, C., Higgins, W., Amador, J., Ambrizzi, T., GarReaud, R., Gochis, D., Gutzler, D., Lettenmaier, D., Marengo, J., Mechoso, C.R., Nogues-Paegle, J., Dias, P.L.S. \& C. ZHANG (2006): Toward a unified view of the American monsoon systems. - In: Journal of Climate 19, 20: 4977-5000.

VERSTAPPEN, H.T. (1977): Remote sensing in geomorphology. - Amsterdam: Elsevier.

Wells, N.A. \& J.A.J. Dorr (1987): Shifting of the Kosi River, northern India. - In: Geology 15, 3: 204-207.

Werding, L. (1977a): Geomorphologie und rezente Sedimentation im Chaco Boreal, Bolivien. - In: Giessener Geologische Schriften 12: 429-446.

WerDING, L. (1977b): The Rio Grande ground-water basin, Chaco Boreal, Bolivia. - In: Geologisches Jahrbuch, Reihe C, Heft C17: 19-36.

Wilkinson, M.J., Marshall, L.G. \& J.G. LundberG (2006): River behavior on megafans and potential influences on diversification and distribution of aquatic organisms. - In: Journal of South American Earth Sciences 21,1-2: 151-172.

\section{Abstract: The Río Parapetí - Holocene megafan formation in the southernmost Amazon basin}

Research on fluvial megafans and foreland basins so far has been mainly concerned with their evolution over geologic timescales, or focused on various aspects of their recent history. This paper documents the landforms on the Río Parapetí megafan in the southernmost Amazon basin in detail in order to unravel changes in geomorphic processes over the Holocene. In addition, new stratigraphic and chronological data from the Bañados de Izozog - an important wetland in the semi-arid Chaco region - is presented. In combination, the data allows the reconstruction of wetland history and suggests significant changes in flow regime and sediment supply of the Río Parapetí throughout the Holocene. In conclusion, these results are discussed in the context of regional environmental change in eastern Bolivia.

Keywords: megafan, Holocene, avulsion, Bolivia, Chaco

\section{Zusammenfassung: Der Río Parapetí - Holozäne Bildung eines Megaschwemmfächers im südlichsten Amazonasgebiet}

Studien der grossen Megafans und Vorlandbecken haben sich bislang vorwiegend mit deren Entwicklung über geologische Zeitskalen beschäftigt oder untersuchten verschiedene Aspekte ihrer rezenten Vergangenheit. Diese Arbeit zielt auf eine detaillierte Darstellung der Formen auf dem Río Parapetí Megafan im südlichsten Amazonas-Becken ab, um Änderungen der geomorphologischen Prozesse im Laufe des Holozäns zu enträtseln. Zusätzlich werden neue Daten zur Stratigraphie und Altersstellung der Bañados de Izozog - eines wichtigen Sumpfgebietes im semi-ariden Chaco - vorgestellt. Insgesamt erlauben diese Daten die Rekonstruktion der Sumpfentwicklung und bieten Einblick in bedeutsame Änderungen des Abfluss- und Sedimentaufkommens des Río Parapetí über das Holozän. Schliesslich werden diese Ergebnisse im Kontext der regionalen Umweltveränderungen in Ostbolivien diskutiert.

Schlüsselwörter: Schwemmebene, Holozän, Flussumlagerung, Bolivien, Chaco

\section{Résumé: Le Río Parapetí - formation holocène d'un mégafan à l'extrême sud du bassin amazonien}

Les recherches sur les mégafans fluviaux et les bassins d'avant-pays ont jusqu'ici plutôt concerné leur évolution au cours des temps géologiques ou focalisé sur certains aspects de leur histoire récente. L'objectif de cet article est de documenter précisément les formes du mégafan du Río Parapetí situé à l'extrême sud du bassin amazonien, afin de comprendre les changements des processus géomorphologiques durant l'Holocène. En outre, l'article présente des données stratigraphiques et chronologiques nouvelles venant des Bañados de Izozog, une importante zone humide située dans la région semi-aride du Chaco. Ces données permettent de procéder à la reconstruction de l'histoire des zones humides et d'interpréter les changements importants des régimes fluviaux et des apports de sédiments du Río Parapetí au cours de l'Holocène. L'article discute finalement ces résultats dans le contexte du changement environnemental régional de l'est de la Bolivie.

Mots-clés: mégafan, Holocène, avulsion, Bolivie, Chaco

Dr. Jan-Hendrik May, School of Earth and Environmental Science, University of Wollongong, 2522 Wollongong NSW, Australia.

e-mail: hmay@uow.edu.au

\section{Manuskripteingang/received/manuscrit reçu le 18.4.2011}

Annahme zum Druck/accepted for publication/accepté pour publication: 12.10 .2011 